\title{
KEBERPIHAKAN NEGARA TERHADAP UPAYA PENGENTASAN KEMISKINAN DI PEDESAAN
}

\author{
Kajian Yuridis Terhadap Undang-Undang Desa
}

\author{
Tutik Nurul Janah \\ Dosen Institut Pesantren Mathali'ul Falah \\ Email: tutik.nurul.janah@gmail.com
}

\begin{abstract}
Desa is the region where the cultural base of Indonesian society. Desa has an important role in an attempt to resolve the problem of poverty. Government spending allocated for development of desa as mandated by the Act No.6 / 2014 should be viewed in the perspective of the state alignments against efforts to resolve the problem of poverty. The state alignments in solving various problems concerning the interests of the Indonesian people can actually be seen from the regulations drawn up and enforced. The state alignments in resolving disputes in pedesaan can be explored through the juridical studies in the Act No. 6/2014 by using analysis from the political perspective of the law.
\end{abstract}

Keywords: The State Alignments, Poverty, Desa.

\begin{abstract}
Abstrak
Desa merupakan letak wilayah dasar budaya masyarakat Indonesia. Desa memiliki peran penting di dalam usaha memecahkan masalah kemiskinan. Pemerintah membelanjakan alokasinya untuk pengembangan desa sebagaimana mandat UU No.6/2014 yang dapat ditinjau dalam perspektif bukum negara sebagai upaya melawan pemecahan permasalahan kemiskinan. Hukum negara dalam memecabkan beragam masalah yang menarik dari masyarakat Indonesia dapat diaktualisasikan dari persiapan aturan dan penguatannya. Hukum negara dalam memecabkan perselisiban di pedesaan dapat dilakukan melalui penyelidikan studi bukum yang tertuang di UU No.6/2014 dengan menggunakan analisis dari perspektifpolitik bukum.
\end{abstract}

Kata Kunci: Hukum Negara, Kemiskinan, Desa. 


\section{A. Pendahuluan}

Kemiskinan merupakan problem yang menghantui negara-negara di dunia. Kemiskinan seolah menjadi benang kusut yang sulit terurai karena problem kemiskinan selalu terkait dengan persoalan sosial kemasyarakatan lainnya. Mengurai persoalan kemiskinan harus berkelindan dengan upaya mencari penyelesaian atas problem pendidikan, kesehatan, ekonomi dan lainnya. Selain itu, upaya mengentaskan kemiskinan harus pula dilihat dari letak lingkungan masyarakat miskin tersebut hidup.

Keberpihakan negara dalam menyelesaikan berbagai persoalan yang menyangkut hajat hidup khususnya pada rakyat Indonesia sebenarnya dapat dilihat dari cara sebuah regulasi disusun dan diberlakukan. Indonesia adalah negara hukum yang menerapkan sistem hukum dominan civil law system. Karenanya, sebagaimana lazimnya civil law system yang menempatkan undang-undang sebagai satu-satunya sumber hukum, maka sebuah peraturan perundang-undangan memiliki kedudukan penting dalam kerangka mendorong sebuah kebijakan agar dapat terealisasi dengan cepat dan tepat guna. Strategi pengentasan kemiskinan masyarakat miskin kota tentu berbeda dengan strategi yang harus diterapkan untuk mengentaskan kemiskinan masyarakat miskin yang tinggal di desa.

Desa adalah letak wilayah basis kultural masyarakat Indonesia berasal. Di pedesaan, penghasilan masyarakat kebanyakan berasal dari sumber daya alam yang ada di sekitar tempat mereka hidup. Masyarakat yang tinggal di pinggiran pantai, kebanyakan memiliki mata pencaharian sebagai nelayan. Sedangkan masyarakat yang hidup di dataran rendah atau pegunungan, kebanyakan mencari sumber penghidupan melalaui bercocoktanam. Namun, menyempitnya lahan pertanian dan perkebunan serta lautan tempat nelayan mencari nafkah yang tak lagi menjanjikan seperti dua dekade silam, menjadi faktor utama terjadinya penurunan kualitas hidup masyarakat desa. ${ }^{1}$ Hal ini kemudian menjadi salah satu pemicu terjadinya urbanisasi, yang dampak lanjutannya adalah meningkatnya jumlah kaum miskin kota.

\footnotetext{
${ }^{1}$ Indonesia memiliki lahan 192 juta ha dengan 67 juta ha merupakan kawasan budidaya atau area penggunaan lain (APL) dengan potensi area pertanian 101 juta ha meliputi lahan basah 25,6 juta ha, lahan kering tanaman semusim 25,3 juta ha, dan lahan kering tanaman tahunan 50,9 juta ha. Lahan pertanian yang telah berbudidaya berjumlah 47 juta ha dan 54 juta masuk kawasan APL. Pada tahun 2013 lahan sawah cenderung menurun dari 8,5 juta ha di tahun 1993 menjadi 8,1 juta ha. Pesatnya sektor industri dan jasa di Jawa khususnya mendorong tingginya laju ekonomi namun mendesak lahan
} 
Kondisi ini merupakan gambaran bahwa desa memiliki posisi strategis dalam upaya memutus rantai kemiskinan. Pemberdayaan ekonomi pedesaan merupakan kata kunci untuk meningkatkan kualitas hidup masyarakat desa dan meminimalisir arus urbanisasi. Karenanya dengan memaksimalkan potensi desa sebagai basis utama pemberdayaan ekonomi masayarakat diharapkan menjadi salah satu solusi dalam upaya mengatasi persoalan kemiskinan secara keseluruhan.

Pemberlakuan Undang-Undang Desa yang awalnya menimbulkan kekhawatiran akan memicu banyaknya perangkat desa yang terjerat dalam korupsi karena kasus penyalahgunaan dana desa, agaknya mesti diminimalisir. Kekhawatiran itu hendaknya dilihat sebagai motivasi bagi perangkat desa khususnya dan warga desa pada umumnya untuk lebih berhati-hati dalam mengelola dan mempertanggungjawabkan dana desa. Namun, lebih dari itu, adanya anggaran jumbo milik negara yang akan digelontorkan untuk desa sesuai dengan amanat UndangUndang No.6/2014 tentang Desa ini semestinya dilihat dari perspektif seberapa besar keberpihakan negara terhadap upaya memutus rantai kemiskinan.

Bentuk upaya pengentasan kemiskinan adalah melalui pemberdayaan masyarakat. Pemberdayaan yang dimaksudkan berupa upaya untuk mendorong masyarakat agar berdaya secara pendidikan, kesehatan dan ekonomi dengan cara memaksimalkan potensi yang dimiliki masyarakat dengan memperkuat potensi yang ada (empowering), membangun iklim agar potensi yang dimiliki masyarakat dapat berkembang (eabling), sehingga masyarakat dapat berdaya secara mandiri dan sustaibnable. Adapun upaya memaksimalkan potensi yang dimaksudkan dapat berarti potensi secara personal maupun potensi secara kolektif sehingga pada akhirnya bisa

pertanian kategori subur. Berdasarkan hasil analisis rente ekonomi lahan (land rent economics) ditemukan rasio land rent penguasaan lahan untuk usaha tani padi dengan penggunaan alokasi perumahan dan industri satu berbanding 622 dan 500 serta selama periode 2009-2010 lahan sawah dinyatakan berkurang sekitar 50 ribu hektar. Diambil dari Rencana Strategis Badan Penelitian dan Pengembangan Pertanian Tahun 2015 - 2019.pdf diakses pada 30 Mei 2017 pukul 08.31 WIB. 
menuju proses perubahan sosial baik secara perilaku, hubungan antar masyarakat sampai dengan pranata sosial seperti demokratisasi, transparansi dan supremasi hukum atau dikenal dengan rekayasa sosial (sosial engineering). ${ }^{2}$ Adapun upaya pemberdayaan masyarakat menurut Jack Rothman dalam three models of community organization practice (1968) yang dikutip Edi Suharto dapat dilakukan melalui tiga model konsep seperti pemberdayaan masyarakat lokal yang berorientasi pada tujuan proses, perencanaan sosial melalui tujuan tugas (task goal), dan melakukan aksi sosial menuju pemerataan (equality) dan keadilan (equity). ${ }^{3}$

Berdasarkan persoalan di atas, tulisan yang berjudul Keberpibakan negara terhadap upaya pengentasan kemiskinan di pedesaan. Kajian yuridis terhadap Undang-Undang Desa, ini akan fokus untuk mejawab pertanyaan bagaimanakah keberpihakan negara dalam melakukan upaya pengentasan kemiskinan. Pertanyaan berikutnya, bagaimanakah keberpihakan negara itu jika dilihat melalui kajian yuridis terhadap Undang Undang tentang Desa. Karena tulisan ini hendak mengkaji keberpihakan negara terhadap suatu masalah melalui pemberlakuan sebuah peraturan perundangundangan, maka, penulis akan melakukan analisa dengan menggunakan sudut pandang politik hukum. Dengan demikian, diharapkan tulisan ini dapat menangkap keberpihakan negara terhadap upaya pengentasan kemiskinan di pedesaan melalui kajian yuridis Undang-Undang No.6/2014 tentang Desa.

\section{B. Keberpihakan Negara dan Politik Hukum dalam Peraturan Perundang- Undangan}

Keberpihakan menurut Kamus Besar Bahasa Indonesia (KBBI) berarti hal berpihak pemerintah kepada rakyat akan meningkatkan kesejahteraan sosial. ${ }^{4}$ Keberpihakan negara merupakan wujud kehadiran negara dalam upaya memenuhi kewajiban utamanya yakni senyejahterakan kehidupan bangsa. Keberpihakan dapat dilihat dari iktikad baik penyelenggara negara dalam berbagai aspek. Diantara wujud keberpihakan negara adalah dengan membaca program legislasi nasional dan arah

2 Aziz Muslim, Dasar-Dasar Pengembangan Masyarakat, (Yogyakarta: Samudra Biru, Cetakan 1, November 2012), Hlm 15-17.

${ }^{3}$ Edi Suharto, Membangun Masyarakat Memberdayakan Rakyat, (Bandung: PT Rafika Aditama, Cetakan 4, Desember 2010), Hlm 37-45.

${ }^{4}$ Dendy Sugono, dkk, Kamus Besar Bahasa Indonesia Pusat Bahasa, (Jakarta: PT. Gramedia Pustaka Utama, 2008, Edisi Keempat, cet.I), hlm.1071. 
kebijakan negara dalam merealisasikan amanah konstitusi ke dalam regulasi yang lebih konkrit dan aplikatif.

Dalam teori pembentukan peraturan perundang-undangan disebutkan bahwa proses penyusunan regulasi selalu bertautan dengan kepentingan-kepentingan terkait regulasi itu sendiri. Karenanya, untuk membaca arah kebijakan dan keberpihakan negara dalam proses pembentukan peraturan perundang-undangan, sangat penting untuk melihatnya dari sudut pandang politik hukum. Politik hukum sebagai pisau analisa biasa digunakan untuk menangkap motif dana arah sebuah kebijakan negara. Dari analisa tersebut akan dapat dipahami bahwa dengan mengetahui motif seseorang -atau dalam hal ini adalah para pemegang kebijakan- maka akan dapat terbaca sejauhmana keberpihakan para pemegang policy negara terhadap persoalan yang dihadapi oleh rakyatnya.

Memahami politik hukum merupakan bagian penting dari upaya menelusuri munculnya sebuah produk hukum yang dalam hal ini adalah peraturan perundangundangan. Politik hukum merupakan garis kebijakan yang menjadi latar belakang sebuah peraturan perundang-undangan dianggap penting untuk diprioritaskan sebagai program legislasi nasional ataupun program legislasi daerah. Bagaimanapun, harus diakui bahwa garis kebijakan tidak bisa dilepaskan dari keberpihakan para pemangku kebijakan. Karenanya, memahami politik hukum sama juga dengan upaya untuk memahami arah kebijakan dan keberpihakan para pemangku kebijakan.

Politik hukum sesungguhnya hadir sebagai pertemuan antara realisme hidup dan tuntutan idealisme. Titik perjumpaan ini penting karena apa yang disebut sebagai das solen (apa yang seharusnya) tidak mungkin sepenuhnya lahir dari das sein (apa yang senyatanya). Idealitas mengenai "apa yang seharusnya" semestinya memiliki nilai-nilai yang paling sentral dan hierarkis, yang atas dasar nilai tersebut diharapkan sebuah perubahan dan perbaikan atas segala sesuatu bersumber. Nilai yang paling sentral dan hierarkis inilah sebenarnya yang disebut sebagai basis ideologis. Posisi ideologi 
sebagai perangkat nilai atau sesuatu yang dipandang cukup mulia untuk diperhatikan, dan menuntut kesetiaan dan ketaatan kita, menyebabkan ideologi berfungsi sebagai suatu "sistem makna" dan makna yang dimaksud (ideologi), tidak lain dari nilai, konsep, gagasan yang dengan hal tersebut sekelompok manusia memahami diri dan dunia mereka. ${ }^{5}$

Secara umum hukum adalah peraturan yang tertulis maupun tidak tertulis yang mengatur manusia dalam hidup bermasyarakat, yang apabila dilanggar maka akan ada sanksi yang tegas. Menurut L.J. Van Apeldoorn hukum adalah kaidah/peraturan-peraturan tingkah laku dan kebiasaan masyarakat. Hukum memiliki kekuatan yang mengatur dan memaksa. ${ }^{6}$ Hukum secara obyektif diartikan sebagai peraturan atau kekuasaan yang bersifat mengatur. Sedangkan hukum secara subyektif diartikan sebagai peraturan yang menyangkut seseorang atau kekuasaan yang diatur oleh hukum obyektif. Tujuan hukum adalah menciptakan kehidupan masyarakat yang damai, berkeadilan dan melindungi kepentingan seluruh masyarakat, disamping kepastian hukum.

Keadilan menurut Aristoteles ada lima, yaitu keadilan distributif dapat diartikan sebagai keadilan yang sebanding dan sesuai dengan jasa masing-masing individu. Selanjutnya keadilan komutatif dipahami sebagai keadilan dengan mengutamakan persamaan tanpa mempertimbangkan aspek resiko dan jasa masingmasing individu. Adapun keadilan kodrat alam diartikan sebagai perlakuan kepada seseorang yang sesuai dengan hukum alam. Contoh, ketika individu membantu individu lain ketika dalam kesulitan maka individu itu akan dibantu oleh individu lain juga. Keadilan konvensional terjadi ketika individu dapat mematuhi peraturan khususnya peraturan perundang-undangan dan keadilan perbaikan terjadi ketika individu telah mencemarkan nama baik individu lain kemudian minta maaf kepada korban lewat media atau secara langsung. ${ }^{7}$ Teori yang semata-mata menghendaki keadilan dalam hukum disebut sebagai teori etis. Teori ini menjelaskan tentang apa

\footnotetext{
5 Bernard L. Tanya, Politik Hukum, Agenda Kepentingan Bersama, (Yogyakarta: Genta Publishing, 2011), hlm..14 2009), hlm.3.

${ }^{6}$ L.J. van Apeldoorn, Pengantar Ilmu Hukum, cet.ke XXX, Jakarta: PT. Pradnya Paramita,

7 Yugi Al on, Penjelasan Lengkap 5 Teori Keadilan Menurut Aristoteles, https://www.eduspensa.id/teori-keadilan-menurut-aristoteles/ diakses pda 30 Mei 2017 pukul 11.35 WIB.
} 
saja yang dianggap adil dan apa saja yang dianggap tidak adil. Pembentukan UndangUndang biasanya diawali dengan pertikaian kepentingan-kepentingan dan tuntutantuntutan demi mencapai keadilan yang diyakini.

Hukum hidup di dalam masyarakat. Hukum disusun oleh manusia dan diperuntukkan bagi kehidupan manusia yang lebih baik. Proses pembentukan sebuah peraturan perundang-undangan sangat dipengaruhi oleh kondisi sosial, ekonomi, politik dan budaya yang melingkupi ketika peraturan perundang-undangan tersebut disusun. Politik hukum menurut Mahfud MD. adalah legal policy atau garis (kebijakan) resmi tentang hukum yang akan diberlakukan, baik dengan pembuatan hukum baru maupun dengan penggantian hukum lama, dalam rangka mencapai tujuan negara. ${ }^{8}$

Definisi mengenai politik hukum yang dirumuskan oleh Mahfud MD. ini sesungguhnya merupakan definisi yang secara substansial memiliki kesamaan dengan definisi mengenai politik hukum yang diberikan oleh para guru besar atau ahli hukum sebelumnya. Dalam definisi tersebut, intinya, Mahfud MD memahami bahwa politik hukum merupakan pilihan tentang hukum-hukum yang akan diberlakukan sekaligus pilihan tentang hukum-hukum yang akan direvisi, dianulir atau bahkan hukum yang tidak lagi diberlakukan. Pilihan tersebut sesungguhnya dimaksudnya untuk mencapai tujuan negara sebagaimana yang tercantum di dalam konstitusi Negara Kesatuan Republik Indonesia, yakni UUD 1945.

Adapun Satjipto Rahardjo mendefinisikan politik hukum sebagai aktifitas pemilih dan cara yang hendak dipakai untuk mencapai suatu tujuan sosial dengan hukum tertentu di dalam masyarakat yang cakupannya meliputi jawaban atas beberapa pertanyaan mendasar, yaitu, 1) tujuan apa yang hendak dicapai melalui sistem yang ada; 2) cara-cara apa dan yang bagaimana yang dirasa paling baik untuk dipakai dalam mencapai tujuan tersebut; 3) kapan waktunya dan melalui cara bagaimana hukum itu perlu diubah; 4) dapatkah suatu pola yang baku dan mapan

${ }^{8}$ Moh. Mahfud MD, Politik. Hukum di Indonesia, (Jakarta: PT Rajawali Pres, 2009), hlm.1 
dirumuskan untuk membantu dalam memutuskan proses pemilihan tujuan serta caracara untuk mencapai tujuan baik tersebut. ${ }^{9}$

Tidak sedikit masyarakat yang masygul melihat bagaimana sebuah produk hukum yang dalam hal ini adalah peraturan perundang-undangan dalam kenyataannya seringkali diwarnai atau bahkan didominasi oleh berbagai kepentingan politik para pemegang kekuasaan. Mengenai hal ini, Mahfudh MD menyatakan bahwa pada kenyataannya hukum memang tidak steril dari subsistem kemasyarakatan lainnya. Politik kerapkali melakukan intervensi atas perbuatan dan pelaksanaan hukum sehingga muncul juga pertanyaan berikutnya tentang subsistem mana antara hukum dan politik yang dalam kenyataannya lebih suprematif. Pertanyaan-pertanyaan lain yang lebih spesifik pun dapat mengemuka seperti bagaimanakah pengaruh politik terhadap hukum, mengapa politik banyak mengintervensi hukum, dst. ${ }^{10}$

Nah, upaya untuk memberikan jawaban atas pertanyaan-pertanyaan di atas merupakan upaya yang sudah memasuki wilayah politik hukum. Politik hukum yang secara sederhana diartikan sebagai kebijakan hukum, yang akan atau telah dilaksanakan secara nasional oleh pemerintah; mencakup pula pengertian tentang bagaimana politik mempengaruhi hukum dengan cara melihat konfigurasi kekuatan yang ada di belakang perbuatan dan penegakan hukum itu. Di sini hukum tidak hanya dilihat sebagai pasal-pasal yang bersifat imperatif atau keharusan-keharusan yang bersifat das sollen, melainkan harus dipandang sebagai subsistem yang dalam kenyataan (das sein) bukan tidak mungkin sangat ditentukan oleh politik. Baik dalam perumusan materi maupun dalam implementasi dan penegakannya. ${ }^{11}$

\section{Upaya Pengentasan Kemiskinan di Pedesaan}

Kemiskinan adalah problem terbesar yang hingga kini masih menghantui negara-negara di dunia. Bukan hanya negara berkembang atau negara yang dalam pernyataan World Bank dinyatakan sebagai negara miskin saja yang mengalami

9 Satjipto Raharjo, Ilmu Hukum (Bandung: Citra Aditya Bakti, 1991), cet.III, hal.352-353. Lihat juga: Moh. Mahfud MD, Politik Hukum di Indonesia, (Jakarta: PT Rajawali Pres, 2009), hlm.2

${ }^{10}$ Moh. Mahfud MD, Politik Hukum di Indonesia, (Jakarta: PT Rajawali Pres, 2009), hlm.9.

${ }^{11}$ Ibid, hlm.9-10 
problem kemiskinan. Namun, negara adidaya pun mengalami persoalan dalam menanggulangi kemiskinan. ${ }^{12}$

Dalam konteks Indonesia, kemiskinan menjadi persoalan bagi masyarakat kota maupun masyarakat yang tinggal di daerah terpencil. Secara umum, jika dilihat dari wilayah tempat masyarakat miskin itu berdomisili, maka masyarakat miskin dapat dibagi dalam dua kategori yakni, masyarakat miskin kota dan masyarakat miskin desa. Baik masyarakat miskin kota maupun masyarakat miskin desa mengalami kemiskinan karena tidak memiliki akses yang setara terhadap pendidikan, kesehatan, kebijakan politik, ekonomi dsb.

Menurut Chamber, kemiskinan adalah suatu integrated concept yang memiliki lima dimensi, yaitu kemiskinan (poverty), ketidakberdayaan (powerless), kerentanan menghadapi situasi darurat (state of emergency), ketergantungan (dependence), dan keterasingan (isolation), baik secara geografis maupun secara sosiologis. ${ }^{13}$ Dalam struktur masyarakat kota, kaum miskin kota adalah kaum marginal yang hidup sebagai gelandangan, pengamen, peminta-minta sedangkan dalam struktur masyarakat desa, kaum miskin adalah buruh tani, pekerja rumah tangga, tuna wisma atau orang yang tidak memiliki akses terhadap sumber daya alam, sumber daya ekonomi, dll.

12 Amerika Selatan terbukti memiliki sejarah penindasan panjang di bawah represi dominasi Amerika Serikat sehingga gelombang berdarah baik kudeta, pemimpin diktator, invasi, korupsi sampai kepada kemiskinan tak terelakkan. Pada masa pemerintahan Allende (1971) di Chili selaku Dewan Keamanan Nasional Nixon dengan paham demokrasinya menyatakan bahwa jika Amerika Serikat tidak mampu mengendalikan Amerika Selatan, maka jangan berbarap untuk mencapai tatanan yang sukses di belahan dunia lain. Amerika Serikat aktif berpolitik dan meletakkan panji liberalisme di Amerika Selatan diantaranya Venezuela. Namun, karena ini negara di Amerika Selatan mengalami kekecewaan yang mendalam terhadap demokrasi dan liberalisasi ekonomi dari Amerika Serikat sehingga keduanya menjadi memanas ketika Presiden Venezuela, Hugo Chavez penganut paham sosialisme melalui "Revolusi Bolivarian" berhasil menjalankan bermacam kebijakan populis dengan melakukan reformasi di bidang ekonomi dan politik berhasil mengentaskan kemiskinan serta mengurangi campur tangan asing dalam perekonomian serta menjadi inspirasi bagi kekuatan kiri di Amerika Selatan. Diambil dari Diah Ayu Pratiwi, Strategi militer... , FISIP UI, 2010.pdf diakses pada 30 Mei 2017 pukul 08.30 WIB

13 Ali Khomsan, dkk, Indikator Kemiskinan dan Misklasifikasi Orang Miskin, (Jakarta: Yayasan Pustaka Obar Indonesia, 2015), hlm.2 
Intinya, baik kaum miskin kota maupun kaum miskin yang hidup di desa adalah masyarakat yang mengalami kemiskinan, ketidakberdayaan, kerentanan mengahadapi situasi darurat, ketergantungan dan keterasingan.

Menanggulangi kemiskinan harus diupayakan dengan melihat bentuk dasar permasalahan kemiskinan itu sendiri. Secara umum, jika menilik pemikiran Chamber, maka kemiskinan dapat dibagi dalam empat betuk. Yakni kemiskinan absolut, kemiskinan relatif, kemiskinan kultural dan kemiskinan struktural. ${ }^{14}$ Pertama; Kemiskinan absolut: apabila pendapatannya berada di bawah garis kemiskinan atau tidak cukup untuk memenuhi kebutuhan hidup minimum yang diperlukan untuk bisa hidup dan berkerja. Kedua; kemiskinan relatif: kondisi kemiskinan karena pengaruh kebijakan pembangunan yang belum menjangkau seluruh masyarakat, sehingga menyebabkan ketimpangan pada pendapatan atau dapat dikatakan orang tersebut sebenarnya telah berada di bawah kemampuan masyarakat sekitar. Ketiga; kemiskinan kultural: mengacu pada persoalan sikap hidup seseorang atau sekelompok masyarakat yang disebabkan oleh faktor budaya, seperti tidak mau berusaha memperbaiki tingkat kehidupan, malas, pemboros, tidak kreatif meskipun ada bantuan dari pihak luar. Keempat; Kemiskinan struktural: situasi miskin yang disebabkan karena rendahnya akses terhadap sumber daya yang terjadi dalam suatu sistem budaya dan sosial politik yang tidak mendukung pembebasan kemiskinan, tetapi kerap menyebabkan suburnya kemiskinan. ${ }^{15}$

Upaya pengentasan kemiskinan harus berkelindan dengan pemecahan persoalan lainnya. Potensi secara personal maupun potensi secara kolektif dapat dilakukan sebagai upaya pemberdayaan masyarakat untuk mendorong masyarakat agar berdaya secara pendidikan, kesehatan dan ekonomi dengan cara memaksimalkan potensi yang mereka miliki. Namun, harus diakui bahwa pemberdayaan ekonomi desa melalui upaya memaksimalkan potensi masyarakat sejauh ini lebih banyak muncul tanpa melibatkan peran negara. Dari sekian ribu kawasan perdesaan di Indonesia, masih banyak kawasan perdesaan yang belum diberdayakan dengan semestinya karena kesadaran untuk memberdayakan diri baru dimiliki oleh sebagian

${ }^{14}$ Ali Khomsan, dkk, Indikator Kemiskinan dan Misklasifikasi Orang Miskin, (Jakarta: Yayasan Pustaka Obar Indonesia, 2015), hlm.3

15 Ibid 1 
kecil masyarakat saja. Ini artinya, negara perlu untuk menunjukkan perannya untuk mendorong agar masyarakat desa berdaya secara ekonomi, pendidikan dan kesehatan. Peran penting negara salah satunya dapat ditunjukkan melalui regulasi yang dapat mendorong pemberdayaan ekonomi kawasan perdesaan.

Pemberdayaan ekonomi desa memiliki kedudukan strategis dalam upaya mengurai problem kemiskinan di Indonesia. Desa sesungguhnya memiliki potensi alam dan sumberdaya manusia yang luar biasa. Namun permasalahannya, masyarakat desa butuh mendapatkan motivasi, pengetahuan, skill, kemampuan manajerial dan wawasan serta dukungan dana agar mampu mengenali dan mengelola potensi yang dimilikinya. Sebagaimana posisi negara dalam memberikan motivasi, membuka peluang bagi masyarakat desa untuk mendapatkan pengetahuan, skill, wawasan, kemampuan managerial serta pendanaan. Maka disitulah peran negara sangat dibutuhkan oleh rakyatnya.

\section{Keberpihakan Negara Terhadap Pengentasan Kemiskinan, Kajian Yuridis Undang-Undang Desa}

Indonesia adalah negara kesatuan yang berbentuk Republik dengan wilayah membentang dari Sabang sampai Merauke. Wilayah yang demikian luas itu secara ketatanegaraan terbagi dalam administrasi pemerintahan daerah. Desa merupakan pemerintahan administratif terkecil dalam struktur ketatanegaraan Negara Kesatuan Republik Indonesia.

Desa menurut Kamus Besar Bahasa Indonesia berarti kesatuan wilayah yang dihuni oleh sejumlah keluarga yang mempunyai sistem pemerintahan sendiri 
(dikepalai oleh seorang kepala desa). ${ }^{16}$ Adapun definisi desa menurut UndangUndang No. 6/2014, Desa adalah desa dan desa adat atau yang disebut dengan nama lain, selanjutnya disebut Desa, adalah kesatuan masyarakat hukum yang memiliki batas wilayah yang berwenang untuk mengatur dan mengurus urusan pemerintahan, kepentingan masyarakat setempat berdasarkan prakarsa masyarakat, hak asal usul, dan/atau hak tradisional yang diakui dan dihormati dalam sistem pemerintahan Negara Kesatuan Republik Indonesia sedangkan Pemerintahan Desa adalah penyelenggaraan urusan pemerintahan dan kepentingan masyarakat setempat dalam sistem pemerintahan Negara Kesatuan Republik Indonesia. ${ }^{17}$

Pedesaan/perdesaan menurut Kamus Besar Bahasa Indonesia adalah daerah pemukiman penduduk yang sangat dipengaruhi oleh kondisi tanah, iklim, dan air sebagai syarat penting terwujudnya pola kehidupan agraris penduduk di tempat itu. ${ }^{18}$ Sedangkan menurut Undang-Undang no.6/2014, kawasan pedesaan diartikan sebagai kawasan yang memiliki kegiatan utama pertanian, termasuk pengelolaan sumber daya alam dengan susunan fungsi kawasan sebagai tempat permukiman perdesaan, pelayanan jasa pemerintahan, pelayanan sosial, dan kegiatan ekonomi. ${ }^{19}$

Desa adalah wilayah dimana basis kultural masyarakat Indonesia berada. Di pedesaan, penghasilan masyarakat kebanyakan berasal dari sumber daya alam yang ada di sekitar tempat mereka hidup. Masyarakat yang tinggal di pinggiran pantai, kebanyakan memiliki mata pencaharian sebagai nelayan, petani garam atau peternak ikan. Sedangkan masyarakat yang hidup di dataran rendah atau pegunungan, kebanyakan mencari sumber penghidupan melalui bercocok tanam. Demikian berlangsung secara turun temurun. Mata pencaharian masyarakat desa tidak bisa dipisahkan dari sumberdaya alam yang ada di sekitarnya.

Namun, harus diakui bahwa sumber penghidupan yang awalnya melimpah, lambat laun mengalami menyusutan. Baik penyusutan secara kualitas maupun

16 Dendy Sugono, dkk, Kamus Besar Bahasa Indonesia Pusat Bahasa, Jakarta: PT. Gramedia Pustaka Utama, 2008).

17 Undang-Undang Nomor 6 tahun 2014 tentang Desa.

18 Dendy Sugono, dkk, Kamus Besar Bahasa Indonesia Pusat Bahasa, Jakarta: PT. Gramedia Pustaka Utama, 2008).

${ }^{19}$ Undang-Undang Nomor 6 tahun 2014 tentang Desa. 
penyusutan secara kuantitas. Penyusutan yang dimaksud disebabkan oleh beragam faktor. Misalnya bagi masyarakat yang hidup di dataran rendah atau pegunungan yang mayoritas mencari nafkah melalui bercocok tanam, maka problem utama mereka adalah penyusutan terkait lahan dan produk pertanian. Misalnya menyempitnya lahan pertanian, semakin sulitnya mencari buruh dan penggarap tanah, mahalnya harga bibit dan pupuk, sulitnya melakukan pemasaran produk pertanian hingga rendahnya harga produk pertanian saat musim panen tiba merupakan faktor-faktor utama penyusutan sumber penghidupan masyarakat desa. Hal ini tidak hanya terjadi pada masyarakat desa yang memiliki sumber penghasilan dari bercocok tanam. Masyarakat nelayan dan petani garam pun mengalami problem penyusutan sumber penghasilan sebagaimana masyarakat petani.

Penyusutan sumber penghidupan akibat penyempitan lahan atau akibat lautan tempat nelayan mencari nafkah yang tak lagi menjanjikan seperti dua dekade silam, menjadi faktor utama terjadinya penurunan kualitas hidup masyarakat desa. ${ }^{20} \mathrm{Hal}$ ini kemudian menjadi salah satu pemicu arus menurunnya minat generasi muda untuk kembali ke desa karena hidup di kota dianggap lebih menarik dan lebih menjanjikan

20 Contoh publikasi di kawasan Pantai Utara Jakarta, membuktikan bahwa pembukaan kawasan mangrove untuk daerah tambak, industri dan permukiman dengan alasan kekurangan lahan terjadi sejak tahun 1960 an. Pada 1963 bahkan pernah dilakukan pembukaan vegetasi besar-besaran sebagai ganti reklamasi pertambakan di daerah Pantai Ancol, sehingga secara fisik pesisir mengalami perubahan yang sangat besar. Selanjutnya di tahun 1980, dibangun jetti pada bagian Barat Muara Angke yang mengakibatkan Pantai Dadap dan Kamal mengalami erosi berat lalu di tahun 1981 terjadi penebangan vegetasi bakau di tepi Utara Delta Angke dan bagian Timur untuk pembangunan pelabuhan Muara Angke. Totok (1994) menyatakan bahwa pada 1981 reklamasi dilakukan menjorok ke laut Pantai Muara Pluit untuk keperluan rumah mewah. Pembukaan kawasan pantai Utara Jakarta besar-besaran ini mengakibatkan perubahan ekologis lingkungan termasuk kehidupan laut dan biotanya. Terkait kegiatan reklamasi ini, mengundang ajakan oleh beberapa pihak terkait yang disebarkan melalui media sosial untuk meliput demonstrasi nelayan Pantai Utara Jakarta pada 17 April 2016. Kegiatan reklamasi ini dianggap menimbulkan perputaran isu yang melibatkan kekuatan ekonomi dan politik sehingga menyeruakkan aroma korupsi. Isu yang ditiupkan berputar mulai soal perijinan yang dipakai sampai dikaitkan dengan pembongkaran pasar ikan, hingga masalah penghilangan penghasilan nelayan di Pantai Utara Jakarta. Diambil dari kompasiana, Nelayan Tidak Bisa Menangkap Ikan Karena Reklamasi, Pikirkan Lagi!, http:/ /www.kompasiana.com/rinsanlumbantobing/nelayan-tidak-bisa-menangkap-ikan-karenareklamasi-pikirkan-lagi_571523dfaa23bd4c20f572de, diakses pada 30 Mei 2017 pukul 11.45 WIB. 
untuk masa depan. Pemuda desa yang pernah mengenyam pendidikan di kota kerapkali memilih untuk melanjutkan hidup di kota karena melihat desa bukanlah tempat yang menjanjikan untuk kehidupan masa depan yang lebih baik. Demikian pula pemuda desa yang mengenyam pendidikan di wilayah pedesaan, berpikir bahwa kehidupan yang lebih menjanjikan hanya dapat dicapai jika mereka mau bekerja dan melanjutkan hidup di kota.

Menurunnya minat para pemuda untuk melanjutkan hidup dan membangun desanya karena desa dianggap bukanlah tempat yang menjanjikan. Sumber penghasilan masyarakat desa yang kebanyakan bergantung pada alam dianggap kurang menarik. Jika kondisi ini terus berlanjut, maka akan banyak sekali dampak lanjutan yang akan menjadi petaka secara sosial, ekonomi dan budaya.

Gambaran di atas sebenarnya menunjukkan bahwa desa memiliki posisi strategis dalam upaya memutus rantai kemiskinan. Pemberdayaan ekonomi pedesaan merupakan kata kunci untuk meningkatkan kualitas hidup masyarakat desa dan meminimalisir arus urbanisasi. Karenanya dengan memaksimalkan potensi desa diharapkan menjadi satu solusi dalam upaya mengatasi persoalan kemiskinan di Indonesia secara keseluruhan.

Meskipun penyusutan sumberdaya alam sebagaimana yang dijelaskan di atas bukan satu-satunya unsur yang memicu penurunan kualitas hidup masyarakat desa, namun hal ini dapat dijadikan salah satu pertimbangan dalam melihat bagaimana seharusnya potensi desa itu dapat dimaksimalkan untuk sebesar-besar kemanfaatan masyarakat di kawasan pedesaan. Hal ini tentu saja dengan mengawali upaya membuka cara pikir dan mengubah perspektif investor dan pemerintah untuk tidak lagi melihat desa dan sumberdaya yang ada di dalamnya semata-mata sebagai obyek investasi dengan pendekatan ekspansif. Namun, harus ada pemahaman ulang mengenai hakekat pemberdayaan ekonomi masyarakat desa dengan mendorong masyarakat desa sebagai penentu utama bagi masa depan mereka sendiri.

Pemberlakuan Undang-Undang Desa sebenarnya merupakan angin segar sebagai wujud dukungan pemerintah untuk mendorong pemberdayaan masyarakat desa. Meski saat awal mula disahkannya peraturan perundang-undangan tentang desa itu memunculkan keprihatinan para pakar hukum karena kekhawatiran dana yang dialokasinya untuk Desa akan diselewengkan, namun regulasi tersebut sebenarnya 
dapat dipandang sebagai motivasi bagi perangkat desa khususnya dan masyarakat desa pada umumnya untuk lebih berhati-hati dalam mengelola dan mempertanggungjawabkan dana desa. ${ }^{21}$ Lebih dari itu, adanya anggaran jumbo milik negara yang akan digelontorkan untuk desa sesuai dengan amanat Undang-Undang No.6/2014 tentang Desa ini semestinya dilihat dari perspektif seberapa besar keberpihakan negara terhadap upaya memutus rantai kemiskinan.

Diantara upaya pengentasan kemiskinan adalah melalui pemberdayaan masyarakat. Pemberdayaan yang dimaksudkan di sini adalah upaya untuk mendorong masyarakat agar berdaya secara pendidikan, kesehatan dan ekonomi dengan cara memaksimalkan potensi yang mereka miliki. Adapun upaya memaksimalkan potensi yang dimaksudkan di sini dapat berarti potensi secara personal maupun potensi

\footnotetext{
${ }^{21}$ Menurut Sutarjo Kartohadikusumo, banyak program pembangunan desa yang mengalami kegagalan diantaranya usaha memberantas fenomena kemiskinan di mayoritas masyarakat pedesaan. Adanya program Alokasi Dana Desa (ADD) masih ditemukan banyak kelemahan sehingga menyebabkan tata kelola ADD masih belum efektif terutama pada kurang berfungsinya lembaga desa, mekanisme perencanaan yang mentah, serta masih rendahnya partisipasi masyarakat karena dominasi kepala desa dan adanya pos anggaran pemanfaatan ADD yang tidak tepat dengan kebutuhan desa. Pemberdayaan masyarakat dalam pemafaatan ADD seharusnya mengacu pada asas pengelolaan keuangan desa yang tertuang dalam Peraturan Menteri Dalam Negeri Nomor 113 Tahun 2014 tentang Pengelolaan Keuangan Desa pasal 2 ayat 1 yang berbunyi: "Keuangan Desa dikelola berdasarkan asas-asas transparan, akuntabel, partisipatif, serta dilakukan dengan tertib dan disiplin anggaran”. Transparansi ini penting agar keuangan desa dapat dikontrol dan diawasi oleh pihak lain yang berwenang serta hak masyarakat dapat memenuhi dan menghindari konflik di masyarakat desa. Partisipasi masyarakat dan para pemangku kepentingan di desa perlu dilibatkan dalam proses perencanaan, pelaksanaan, monitoring, hingga sampai pada tahap evaluasi kegiatan yang telah dilaksanakan sehingga pengelolaan dana sesuai kebutuhan masyarakat dan bukan keinginan elit desa saja. Keuangan desa yang tertib dan disiplin anggaran, taat hukum perlu diiplementasikan dan dilaksanakan secara konsisten juga dilakukan pencatatan sesuai dengan prinsip akuntansi keuangan di desa sehingga peningkatkan profesionalitas pengelolaan dapat tercapai. Tata kelola dana desa yang direncanakan bisa menjadi perkiraan yang terukur secara rasional sehingga dapat dicapai untuk setiap sumber pendapatan. Diambil dari Tata Kelola Alokasi Dana Desa yang Tepat Sasaran untuk Kepentingan Pembangunan Masyarakat, http://www.kompasiana.com/ayuningtyassuciani/tata-kelola-alokasi-dana-desa-yang-tepat-sasaranuntuk-kepentingan-pembangunan masyarakat_5692b102b47a61cc0dfbbf9d, diakses pada 30 Mei 2017 pukul 11.05 WIB.
} 
secara kolektif. Menurut Pasal 1 Undang-Undang No.6/2014 tentang Desa, yang dimaksud dengan Pemberdayaan Masyarakat Desa adalah upaya mengembangkan kemandirian dan kesejahteraan masyarakat dengan meningkatkan pengetahuan, sikap, keterampilan, perilaku, kemampuan, kesadaran, serta memanfaatkan sumber daya melalui penetapan kebijakan, program, kegiatan, dan pendampingan yang sesuai dengan esensi masalah dan prioritas kebutuhan masyarakat Desa.

Undang-Undang No.6/2014 tentang Desa sesungguhnya memberikan peluang kepada masyarakat desa untuk mengembangkan wilayahnya dengan memanfaatkan sumberdaya yang dimilikinya. Dengan pengembangan potensi yang dimilikinya, maka dimensi kemiskinan sebagaimana yang dijelaskan oleh Chamber yang meliputi: Kemiskinan, ketidakberdayaan, kerentanan menghadapi situasi darurat, ketergantungan, dan keterasingan, baik secara geografis maupun secara sosiologis, yang juga dialami oleh masyarakat miskin yang tinggal di kawasan pedesaan, lambat laun akan dapat terurai dengan semestinya.

Menurut teori pertumbuhan ekonomi, pertumbuhan ekonomi lokal dipengaruhi oleh beberapa faktor, yaitu: Sumber daya alam, investasi kapital, tenaga kerja, kewirausahaan, belanja pemerintah, kapasitas pemerintah lokal, situasi ekonomi internasional, infrastruktur, transportasi, komunikasi dan energi. ${ }^{22}$ Penyusutan sumber penghasilan masyarakat desa yang menjadi pemicu problem kemiskinan, akan dapat diurai dengan cara memaksimalkan potensi yang menjadi faktor pendorong pertumbuhan ekonomi lokal.

Keberpihakan negara terhadap pengentasan kemiskinan di pedesaan melalui pengesahan Undang-Undang No.6/2014 tentang Desa, paling tidak dapat dilihat melalui beberapa Pasal yang termuat di dalamnya. Secara umum, jika mengaitkan antara faktor pendorong pertumbuhan ekonomi lokal dan Pasal-Pasal yang tertera dalam Undang-Undang No.6/2014, maka terdapat beberapa ketentuan kunci yang dapat menjadi variabel dalam mengkaji keberpihakan negara terhadap upaya pengentasan kemiskinan di pedesaan. Pasal yang dimaksud ialah Pasal terkait Kewenangan Desa, Pasal terkait Hak dan Kewajiban, Pasal terkait Pengelolaan Aset dan Keuangan Desa serta Pasal terkait Badan Usaha Milik Desa (BUM Desa)

22 Yusuf Wally, Percepatan Pembangunan dan Kemandirian Kampung, (Yogyakarta: BPFEYogyakarta, 2013), hlm.19. 
Mengenai kewenangan Desa, dapat dilihat dalam Pasal 18 Undang-Undang No.6/2014 tentang Desa yang menyatakan bahwa "kewenangan Desa meliputi kewenangan di bidang penyelenggaraan pemerintahan Desa, pelaksanaan pembangunan Desa, pembinaan kemasyarakatan Desa, dan pemberdayaan masyarakat Desa berdasarkan prakarsa masyarakat, hak asal usul, dan adat istiadat Desa." Paling tidak, terdapat tiga hal penting yang patut diperhatikan terkait Pasal 18 yang memuat ketentuan mengenai kewenangan desa ini. Pertama, Pasal 18 Undang Undang No.6/2014 ini menunjukkan bahwa negara secara substantif memberi kewenangan kepada perintah desa dalam menyelenggarakan pemerintahan di wilayahnya. Kedua, negara mendorong pemerintah desa untuk melakukan pemberdayaan masyarakat dengan basis potensi dan manajemen yang dikelolanya sendiri. Ketiga, negera mengakui hak asal-usul dan adat istiadat yang telah berlangsung secara turun-temurun. Keberadaan Pasal 18 ini sangat penting dalam memposisikan kedudukan dan kewenangan pemerintah desa dan masyarakat di kawasan pedesaan. Penyebutan kewenangan yang dimiliki pemerintah desa dalam menyelenggarakan pemerintahan Desa dan pemberdayaan ekonomi akan membawa konsekuensi yang besar terhadap cara pandang masyarakat desa terhadap pengelolaan sumberdaya alam maupun potensi-potensi lainnya yang dimilikinya. Pasal 18 ini dapat pula diartikan sebagai bentuk kepercayaan dan pengakuan negara terhadap pemerintah desa dan masyarakat desa dalam mengelola kekayaan alam yang dimilikinya untuk sebesar-besarnya kesejahteraan masyarakat desa.

Mengenai Hak dan Kewajiban dalam Pasal 67 Ayat (1) menyatakan bahwa: "Desa berhak: a. mengatur dan mengurus kepentingan masyarakat berdasarkan hak asal usul, adat istiadat, dan nilai sosial budaya masyarakat desa; b. menetapkan dan mengelola kelembagaan desa; dan c. mendapatkan sumber pendapatan." Pasal 67 ini memiliki dua arti penting. Pertama; pemerintah secara konstitusional memberikan ruang kepada masyarakat desa untuk mengurus dan mengembangkan diri 
berdasarkan local wisdom dan adat istiadat yang dimilikinya. Kedua; pemerintak mendorong masyarakat desa untuk menetapkan dan mengelola kelembagaan serta mendapatkan sumber penghasilannya sendiri sesuai dengan potensi dan kebutuhan masing-masing desa.

Adapun terkait Pengelolaan Kekayaan Milik Desa sebagaimana yang termaktub dalam Pasal 77 Ayat (1) dinyatakan bahwa pengelolaan kekayaan milik Desa dilaksanakan berdasarkan asas kepentingan umum, fungsional, kepastian hukum, keterbukaan, efisiensi, efektivitas, akuntabilitas, dan kepastian nilai ekonomi. Ayat (2) Pengelolaan kekayaan milik desa dilakukan untuk meningkatkan kesejahteraan dan taraf hidup masyarakat desa serta meningkatkan pendapatan desa. Ayat (3) Pengelolaan kekayaan milik desa sebagaimana dimaksud pada ayat (2) dibahas oleh Kepala Desa bersama Badan Permusyawaratan Desa berdasarkan tata cara pengelolaan kekayaan milik desa yang diatur dalam Peraturan Pemerintah. Apa yang tertera dalam Pasal 77 ini menunjukkan bahwa sudah seharusnya desa tidak lagi semata dilihat sebagai wilayah dengan kekayaan alam melimpah yang menjanjikan untuk dieksploitasi oleh investor asing. Pasal mengenai pengelolaan kekayaan milik desa merupakan dukungan negara agar masyarakat desa memberdayakan potensi dan sumberdaya yang dimilikinya dengan kesadaran penuh bahwa kekayaan alam semstinya dikelola untuk sebesar-besarnya kemanfaatan warga yang ada di sekitarnya. Dalam hal ini, pengembangan ekonomi desa dilakukan dengan basis pemberdayaan ekonomi masyarakat pedesaan, bukan melulu menjadikan kekayaan alam desa sebagai asset negara yang dijual dan/atau dikelola investor asing secara eksploitatif.

Sedangkan Pasal tentang Badan Usaha Milik Desa merupakan Pasal yang mempertegas mengenai posisi negara dalam mendukung pemberdayaan ekonomi masyarakat sebagai bagian dari upaya mengentas kemiskinan di pedesaan. Pada Pasal 87 Ayat (1) menyatakan desa dapat mendirikan Badan Usaha Milik Desa yang disebut BUM Desa. Ayat (2) BUM Desa dikelola dengan semangat kekeluargaan dan kegotong-royongan. Ayat (3) BUM Desa dapat menjalankan usaha di bidang ekonomi dan/atau pelayanan umum sesuai dengan ketentuan peraturan perundangundangan. Pasal 88 Ayat (1) Pendirian BUM Desa disepakati melalui Musyawarah Desa. (2) Pendirian BUM Desa sebagaimana dimaksud pada ayat (1) ditetapkan dengan Peraturan Desa. Pasal 89 Ayat (1) Hasil usaha BUM Desa dimanfaatkan 
untuk: a. pengembangan usaha; dan b. Pembangunan desa, pemberdayaan masyarakat desa, dan pemberian bantuan untuk masyarakat miskin melalui hibah, bantuan sosial, dan kegiatan dana bergulir yang ditetapkan dalam Anggaran Pendapatan dan Belanja Desa.” BUM Desa merupakan bentuk dukungan agar masyarakat desa mengusahakan terwujudnya usaha kolektif yang mendudukkan masyarakat desa sebagai pemegang saham pengendali bagi perusahaan yang didirikan oleh pemerintah desa. BUM Desa merupakan solusi konkret bagi upaya pengentasan kemiskinan melalui kerja kolektif.

Kehidupan masyarakat di kawasan pedesaan yang cenderung bersifat kekeluargaan sesungguhnya merupakan modal utama bagi upaya pemberdayaan masyarakat desa. Namun, modal utama itu akan benar-benar dapat dikembangkan untuk sesuatu yang menguntungkan jika dibarengi dengan skill dan manajemen yang baik. Karenanya, Jika keberpihakan negara terhadap pemberdayaan masyarakat kawasan pedesaan sebagai bagian penting dari upaya pengentasan kemiskinan, maka menurut teori penyusuan perundang-undangan, negara memiliki keberpihakan yang cukup besar. Namun, akan berbeda jika kajian teoritik ini dikembangkan menjadi kajian implementasi peraturan perundang-undangan.

Dalam implementasinya, upaya pengentasan kemiskinan di pedesaan melalui pemberdaayan potensi dan sumberdaya desa yang secara hukum telah dipayungi oleh peraturan perundang-undangan, masih perlu mendapatkan dukungan yang lebih nyata di tingkat realisasi di lapangan. Hal ini karena pengembangan potensi dan sumberdaya desa tidak mungkin akan mencapai seperti yang diharapkan jika tidak didukung oleh penguasaan skill dan manajemen yang baik sehingga keberlangsungan usaha yang disokong secara kolektif oleh masyarakat desa melalui pemerintah desa dan pendirian BUM Desa dapat terlaksana secara berkesinambungan. 


\section{E. Penutup}

Keberpihakan negara dalam melakukan upaya pengentasan kemiskinan memang tidak dapat dilihat dari satu sudut pandang saja. Jika dilihat melalui perspektif politik hukum, maka pengesahan dan pemberlakuan Undang-Undang Nomor 6 tahun 2014 tentang Desa dapat dilihat sebagai wujud keberpihakan negara terhadap upaya pengentasan kemiskinan di pedesaan. Kemiskinan selalu menjadi menjadi problem yang saling berkelindan dengan persoalan sosial ekonomi lainnya. Karena posisi strategis desa sebagai bagian penting dalam mengurai persoalan kemiskinan di Indonesia, maka keberpihakan negara melalui pemberlakuan UndangUndang Desa terhadap upaya pengentasan kemiskinan di pedesaan, diharapkan menjadi bagian penting dalam ikhtiar menyejahterakan rakyat Indonesia secara keseluruhan.

Fokus tulisan ini adalah melihat keberpihakan negara dalam upaya pengentasan kemiskinan di pedesaan dalam kacamata peraturan perundang-undangan secara teoritik. Karenanya, secara dalam perspektif politik hukum, keberpihakan pemerintah cukup besar jika dilihat dalam pasal-pasal yang tertuang dalam UndangUndang No.6/2014, terutama ketentuan mengenai Kewenangan Pemerintah Desa, Pemberdayaan Masyarakat dan BUM Desa. Penelitian ini akan lebih lengkap jika diteruskan dengan penelitian lanjutan mengenai kajian tentang implementasi UndangUndang No.6/2014 sebagai realisasi dari kebijakan negara terhadap upaya pengentasan kemiskinan di pedesaan. 


\section{Daftar Pustaka}

Apeldoorn, L.J. van, Pengantar Ilmu Hukum, cet.ke XXX, Jakarta: PT. Pradnya Paramita, 2009.

Khomsan, Ali, dkk, Indikator Kemiskinan dan Misklasifikasi Orang Miskin, Jakarta: Yayasan Pustaka Obar Indonesia, 2015.

Khomsan, Bernard L., Politik. Hukum, Agenda Kepentingan Bersama, Yogyakarta: Genta Publishing, 2011.

Kompasiana, Nelayan Tidak Bisa Menangkap Ikan Karena Reklamasi, Pikirkan Lagi!, http://www.kompasiana.com/rinsanlumbantobing/nelayan-tidak-bisamenangkap-ikan-karena-reklamasi-pikirkan-lagi_571523dfaa23bd4c20f572de, diakses pada 30 Mei 2017 pukul 11.45 WIBMD, Moh. Mahfud, Politik Hukum di Indonesia, Jakarta: PT Rajawali Pres, 2009.

Muslim, Aziz, Dasar-Dasar Pengembangan Masyarakat, Yogyakarta: Samudra Biru, 2012.

On, Yugi Al, Penjelasan Lengkap 5 Teori Keadilan Menurut Aristoteles, https://www.eduspensa.id/teori-keadilan-menurut-aristoteles/ diakses pda $30 \mathrm{Mei}$ 2017 pukul 11.35 WIB.

Pratiwi, Diah Ayu, Strategi militer... , FISIP UI, 2010.pdf diakses pada 30 Mei 2017

pukul 08.30 WIB

Raharjo, Satjipto, Ilmu Hukum, Bandung: Citra Aditya Bakti, 1991, cet.III.

Rencana Strategis Badan Penelitian dan Pengembangan Pertanian Tahun 2015 2019.pdf diakses pada 30 Mei 2017 pukul 08.31 WIB.

Suharto, Edi, Membangun Masyarakat Memberdayakan Rakyat, Bandung: PT Rafika Aditama, 2010.

Sugono, Dendy, dkk, Kamus Besar Bahasa Indonesia Pusat Bahasa, Jakarta: PT. Gramedia Pustaka Utama, 2008.

Tata Kelola Alokasi Dana Desa yang Tepat Sasaran untuk Kepentingan Pembangunan Masyarakat, http://www.kompasiana.com/ayuningtyassuciani/tatakelola-alokasi-dana-desa-yang-tepat-sasaran-untuk-kepentingan-pembangunan masyarakat_5692b102b47a61cc0dfbbf9d, diakses pada 30 Mei 2017 pukul 11.05 WIB

Undang-Undang Nomor 6 tahun 2014 tentang Desa 
TUTIK NURUL JANAH

Wally, Yusuf, Percepatan Pembangunan dan Kemandirian Kampung, (Yogyakarta: BPFEYogyakarta, 2013 